\title{
ELENA FERRANTE AND PATRIARCHY. LESSONS FROM L'AMICA GENLALE (MY BRILLIANT FRIEND)
}

\author{
Maria Clara Calheiros ${ }^{1}$
}

\section{Abstract}

The relationship between feminist theories and the law and literature movement is not new and has provided very fruitful analysis over many decades, ever since the 1970s. Twentyfirst century literature, which includes L' Amica Geniale (My brilliant friend), even when describing stories and action that are placed in other historical times (in this case, in the historical context of the twentieth century), allows establishing an ever renewed dialogue with feminist theories, in its current expression. The author reviews the recent "rediscovery" of feminism and how some concepts evolved in the context of feminist theories. A concept to which she devotes attention is patriarchy, as it is paramount for understanding the connections that can be perceived to exist between feminist theories and FERRANTE's work. In the author's opinion, the Neapolitan novels are eloquent in the portrait presented - complex, multifaceted, ambiguous even - of what it ultimately means to be a woman living in a patriarchal society.

\section{Keywords}

Law and Literature. Patriarchy. Feminist Theories. Elena Ferrante. Gender equality.

\section{Summary}

1. Introduction. 2. The concept of "patriarchy" within feminist theories. 3. My brilliant friend and feminism. 4. Elena and Lila. Final remarks. References

\footnotetext{
${ }^{1}$ Full professor. Faculty of Law. Minho University - Portugal.
} 
'Even today, after a century of feminism, we can't fully be ourselves, don't belong to ourselves. Our defects, our cruelties, our crimes, our virtues, our pleasure, our very language are obediently inscribed in the bierarchies of the male, are punished or praised according to codes that don't really belong to us and therefore wear us out. It's a condition that makes it easy to become odious to others and to ourselves. To demonstrate what we are with an effort at autonomy requires that we maintain a rutbless vigilance of ourselves."

Elena FERRANTE

"Even today, after a century of feminism, we can't fully be ourselves" The Guardian

Sat., 17 Mar. 2018

\section{INTRODUCTION.}

The initial inspiration for this paper came from the reading of Elena FERRANTE's novel, L'amica geniale. FERRANTE's narrative triggered in me a certain perplexity, requiring prolonged thought. Reflecting on the story of the two friends, Elena and Lila, central figures of the work in question, enabled realizing the extreme richness of their characterisation and plot construction. It also strikes me how easy it was to find points of contact with perspectives and analyses that feminist theories, particularly the most recent ones, had offered us on the "issues of women." This was especially true in what regards one concept, in particular: that of patriarchy. It seemed beyond doubt that FERRANTE's novel was a critical staging of patriarchal society and the position of women in it. L'amica Geniale confronted us with their struggles, their challenges and limitations, with women's need for constant personal overcoming.

This exercise, to which we will dedicate this paper, has already been carried out on multiple occasions concerning other works of literature, so it is not new. However, twenty-first century literature, which includes L'Amica Geniale, even when describing stories and action that are placed in other 


\section{Clara Calheirosl ElenaFerrantiand Patriarchyl ISSN 2675-1038}

historical times (in this case, in the historical context of the twentieth century), allows establishing an ever renewed dialogue with feminist theories, in its current expression.

In the following pages, I will begin by reviewing the recent "rediscovery" of feminism and how some concepts evolved in the context of feminist theories. A concept to which our attention will be especially devoted is patriarchy, as it is paramount for understanding the connections that we perceive to exist between feminist theories and FERRANTE's work.

Once we finish our overview of feminism and the development of the concept of patriarchy, we will pursue the analysis of L'Amica Geniale's narrative in a feminist perspective. By scrutinising the main characters' features (in particular the one of the protagonist, Elena Greco), as well as by looking into some of the episodes that are part of the fictional plot, we will then seek to highlight the existing connections between the novel and the feminine experience of the world, as it is depicted through the eyes of feminism.

\section{THE CONCEPT OF "PATRIARCHY" WITHIN FEMINIST THEORIES}

The concept of patriarchy seems to have re-entered academic and media discourses in recent times ${ }^{2}$, after being absent for several decades because it

2 As a testimony to this return of «patriarchy» to public debate, see the article authored by Charlotte Higgins published on the 22 ${ }^{\text {nd }}$ June 2018 in the British newspaper The Guardian, under the suggestive title The age of patriarchy: how an unfashionable idea became a rallying cry for feminism today https://www.theguardian.com/news/2018/jun/22/the-age-of-patriarchyhow-an-unfashionable-idea-became-a-rallying-cry-for-feminism-today [last access 14.01.2020] 
was regarded as obsolete ${ }^{3}$. In my opinion, this does not mean that the term has become consensual today or even that whoever uses it fully understands its true meaning ${ }^{4}$. It can be surely asserted that the second decade of the 21 st century was marked by renewed concern for gender equality, multiple examples of which could be offered. One of them, which is especially close to me, is the inclusion of this topic among the research goals that the Institutions of the European Union have been concerned with, and thus funded.

${ }^{3}$ Indeed, for several reasons that we cannot explore here, not only has academia ceased to be interested in feminist theories and the study of the issues these have brought to the debate, especially in the philosophical-legal sphere, but, in addition, the social movement and activism focused on "women's issues" seemed to have weakened substantially, even in countries such as the United States of America. On this regard Kristin KALSEM and Verna WILLIAMS stated: "According to recent research by the Centre for the Advancement of Women, less than half the women who were surveyed believed there was a need for a strengthened women's movement. 35 Specifically, $43 \%$ of all surveyed women so believed; however, for women of colour, the numbers were much higher, with $63 \%$ of Black women and $68 \%$ of Latina women voicing support for a stronger women's movement. Similarly, Black and Latina women were more likely to characterize themselves as "feminists." Yet many women are disaffected from the movement, finding that it has invested its energies in those who are privileged because of their race, class, able-bodied status, and/or sexual orientation". KALSEM et al 2012, 137.

${ }^{4} \mathrm{Na}$ verdade, há que reconhecer que os problemas de indeterminação terminológica afectam as teorias feministas, em geral. O primeiro problema é mesmo o de encontrar uma definição para o termo "feminista" e para o que seriam "teorias feministas". In this regard, Patricia CAINE states that: "It is difficult enough to define "feminism", let alone "feminist jurisprudence". No single definition could possibly capture the richness and diversity of feminist thought. [...] I take the position that legal scholarship is not feminist unless it is grounded in women's experience, an experience which produces a feminist point of view. Substantively, there can be differences of opinion among feminists, 7 differences that result from different points of view. I do not take the position either that there is one correct feminist viewpoint or that only women can develop a feminist viewpoint. I focus on method rather than substance. One must listen carefully to women's life stories to develop a feminist point of view". CAINE 1992, 20. 
The rise of the \#Me'Too movement, the radical and newsworthy protests of the Femen Ukrainian activists, the actions of older activist groups such as the guerrilla girls (feminist activists focused on promoting gender equality within the art world), the emergence of prominent lawsuits, involving abuses committed by leading movie stars and entrepreneurs, music or political public figures, raising huge public interest, among many other phenomena, draw attention towards "women's issues" agenda and, subsequently, favoured the recovery of previously abandoned feminist discourse. This has promoted the resurgence of terms and ideas associated with feminism. Such is the case with patriarchy.

It would not be possible, nor is it our purpose, to carry out, along these few pages, a review of the historical process of development of feminism, in its successive "waves." Still, it is important to remember that the historical claims for equal rights for men and women, and equal access to the sphere of "public" life in western countries (which is, to a large extent, the backdrop in which the resurgence of feminism currently takes place), were gradually addressed, in an ever more effective way. This has led to an apparent emptying of the core demands that had supported feminist movements and, therefore, justified the need to assert ourselves as "feminists." In fact, if there were no longer professions prohibited to women; if reproductive rights were protected; if special benefits were granted to deal with constraints imposed by motherhood; if equality between human beings, regardless of gender, became a principle enshrined in every democratic constitution and in every universal or regional declaration of rights; if positive discrimination measures had been adopted to encourage a more significant participation of women at the top of political, academic and business organisations, what reasons would there be to call -- still and always -- for more equality?

Moreover, in many Western social circles, women began to reject the connotation with feminism, fearing that this would be associated with the most extreme and radical forms of historical feminist activism. The word "feminism," as well as other terms that were associated with it, such as 
"patriarchy," were excluded from political and academic discourse, relegated to the status of historical study objects and nothing more.

As we have already stated, in the recent past, several factors contributed to once again putting gender equality on the political agenda. This was certainly the case of media attention and renewed public concerns on women's issues. And here is how we witness the reappearance of terms such as "patriarchy" in academic literature and political discourse.

The goal I have set out is to demonstrate the existence of a relationship between this concept of "patriarchy" - and all that surrounds it - and Elena Ferrante's novel My brilliant friend. Therefore, we believe it is necessary to try to briefly expose the development and outline of this concept within feminist theories.

The concept of patriarchy is meant to convey the very idea of women's historical oppression, throughout different human societies and ages, through a network of social, economic, family, educational, and cultural relationships, intertwined with each other. By characterising patriarchy, in our view, the idea is to demonstrate that the oppression of women is not only the outcome of existing legal norms and political structures that instituted inequality between men and women. This oppression and this inequality are also the product of the social organisation of the private sphere, namely, the household, family and the way labour relationships are organised. Consequently, the normativity that provides the basis for the patriarchal system is cultural in nature and finds expression in tradition, education and even religion itself. Moreover, it is enough to think of Christianity and the figure of Mary, among other biblical examples of women, so that we clearly envisage the set of virtues that all women should cultivate.

Through the concept of patriarchy, rather than focusing on concrete acts of women's discrimination, what is highlighted by feminism is how the world, society and women's subordination restrict our existence as individuals. This world, this society, devises roles and assigns them to us, and expect 
individual performances that conform to these stereotypes. Thus, men and women, quite the same way, to the extent that they fit the roles and models of expected behaviour and lifestyle, without questioning them, are both unconscious participants of the system and constantly contribute to the continuous reproduction of norms and structures that perpetuate inequality. ${ }^{5}$.

In short, by bringing to the forefront the concept of patriarchy, feminist theories manage to give us a deep insight into the reasons for inequality, the role that men and women play in its perpetuation and the irrelevance of single and casuistic achievements of equal rights in regard of the perceived goal of finally ending women's oppression. Within the patriarchal system, we are all accomplices in the reproduction of insidious and subtle behaviour models, as we adjust our actions to cultural norms that constitute, after all, the backbone of that very system.

On the other hand, another advantage of disconnecting the issue of women's oppression from the casuistic fight against discriminatory legal norms consists of enabling us to find a satisfactory explanation for the universal subordination of women, in spite of all the differences that result from the diversity of features we acknowledge to exist between countries and continents.

The explanation of the concept of "patriarchy" was not only a task embraced by feminist theories but was also expressed through literature.

${ }^{5}$ Kate MILLET explains this idea well: "Under patriarchy, the human race is divided into two castes, and personal identity is determined by birth and sex group. Conformity is carefully cultivated through socialization and nonconformity is punished. Masculinity and femininity is who we are or should be. Make a gesture associated with the other sex and you will be marginalized and stereotyped. In addition to the male/female categories, the compulsive system of heterosexuality is enforced - born into one identity, you do not switch or cross over, swap clothes, or transgress. Punishments here are terrible and have succeeded in producing obedience throughout history. Imagine challenging them". MILLET 2000, 660. 
Moreover, it was no coincidence that feminist theories and the Law and Literature movement would cross paths, with huge advantages for advancing the struggle for gender equality.

One of these literary examples, most often quoted by feminist theories, has been Virginia Woolf's book Three Guineas, published in 1938, where the author tries to answer a question addressed to her: "how to avoid war." In doing so, Virginia Woolf outlines the framework of patriarchal society and critically discusses on the topics of women's education, restrictions faced on trying to be part of the workforce and their access to the public sphere. In the book, Virginia Woolf calls into question the social rules that determine women's place in the world and expresses her clear belief that the patriarchal system is supported by several layers of normativity, all different in nature ${ }^{6}$. The author goes so far as to establish an explicit parallelism between the fight against patriarchy and the fight against fascism.

Finding echoes of concepts devised by feminist theories in literary works, namely the concept of patriarchy, is, therefore, not something original or new. Still, literature still has much to offer in understanding our existence,

${ }^{6}$ The author states: "According to Antigone there are two kinds of law, the written and the unwritten, and Mrs Drummond maintains that it may sometimes be necessary to improve the written law by breaking it. But the many and varied activities of the educated man's daughter in the nineteenth century were clearly not simply or even mainly directed towards breaking the laws. They were, on the contrary, endeavours of an experimental kind to discover what are the unwritten laws; that is the private laws that should regulate certain instincts, passions, mental and physical desires. That such laws exist and are observed by civilized people, is fairly generally allowed; but it is beginning to be agreed that they were not laid down by 'God', who is now very generally held to be a conception, of patriarchal origin, valid only for certain races, at certain stages and times; nor by nature, who is now known to vary greatly in her commands and to be largely under control; but have to be discovered afresh by successive generations, largely by their own efforts of reason and imagination". Three Guineas. http://gutenberg.net.au/ebooks02/0200931h.html [consultado em 14.01.2020] 
through its interpretations of reality. As we will try to demonstrate further ahead, we think that this is the case with Elena FERRANTE's work.

It is true that the evolution of feminist theories has given rise to a variable use of the concept of patriarchy. This concept is paramount in the works of second-wave feminists ${ }^{7}$,

7 Traditionally, the different stages of the feminist movement historical development are represented by the use of the word "wave". The first wave of feminism intended to claim citizenship rights for women, as a social group. As citizens, women were excluded from the public sphere and made invisible. A particularly striking moment, historically, was the first convention on women's rights, which took place in the U.S. city of Seneca Falls in 1848. There was ratified the Declaration of Sentiments, claiming for the United States' Declaration of Independence was also applied to women. During the following decades, and already in the twentieth century, the first wave of feminism gradually accumulated victories in the elimination of legal discrimination of women and, coincidentally, ensuring women a place in public life identical to that of man: being able to vote, to be able to pursue a profession, have access to education, to be the holder of the right to property, etc. Of course, many of these advancements have taken place at a different pace in different geographies and in different historical moments. It is generally recognized that the outbreak of the two world wars in the 20th century forced belligerent states to resort to women's labor, allowing many women to have a paid job for the first time in generations and, therefore, forever changing the features of the work force.

The second wave of feminism is situated in the seventies of the 20 th century. This feminism is confronted with a patriarchal world, where differences between men and women remain, despite the progress made in women's legal status. It is recognized that substantial inequalities persist at different levels and there is now a focus on the issues of sexuality and reproduction, that is, in the private sphere. In this regard, Kate MILLET, a second wave feminist, explains the challenges that the feminism of the seventies has faced: "Patriarchy essentially hates and fears sexuality. In women, patriarchy sees sexuality as evil and sin. In men, sexuality is sometimes freedom, sometimes just dangerous, but in women it must be a dire consequence, a vulnerability, shameful and debilitating. A great deal of the impetus of the second wave of American feminism has been toward sexual freedom and sexual expression for women, and also toward the liberation of sexual orientations other than compulsive heterosexuality. Here, the new women's movement is aligned with gay liberation. As lesbians are women too, the second wave has battled for them and challenged 
such as Kate MILLETT, Rosalind COWARD or Catharine MACKINNON $^{8}$.

Kate MILLET expressed in this eloquent manner, and to some extent summarising the essentials the feminists' views of her generation on the concept of patriarchy:

"Under patriarchy, women did not, and still do not, have much in the way of a public or larger social existence. Political theorists from Plato to Habermas do not see women as having public existence, still less public office. Throughout patriarchal history, women have not been citizens in the way that men have been who enjoy both the public and private sphere. Confined to the home and child care, women are controlled by the pater familias, as the heads of household are controlled by the state." 9

Of course, throughout the seventies and eighties, in the multiple debates in which the term "patriarchy" was present, feminists were introducing constant reformulations and refinements to it. The main features of patriarchy are related to sexuality and women's subordination this implies,

the heterosexual norm and the very notions of masculinity and femininity". MILLET 2000, 662.

Third-wave feminism had its birth marked in the US in 1991, when the young activist Rebecca WALKER famously wrote in Ms. Magazine: 'I am not a post feminism feminist. I am the Third Wave.' Third-wave feminism asserts itself and develops, generically, as opposed to the previous generation. There is, to a large extent, a rejection of the woman's victimization discourse, which they claim to be a feature of the second-wave feminism, especially in regard of issues such as sexuality, pornography or prostitution. Cfr. CRAWFORD 2010, 100-102.

8 Several authors and works could be cited in this regard: EISENSTEIN 1988; MACKINNON 1989; SMART 1989.

${ }^{9}$ MILLET 2000, 663. For a more recent and complete overlook on patriarchy: WILLIAMS 2016, 61-84; IRONS 2018, 479-522. 
within the context of traditional societies. Patriarchy is also deemed to be clearly linked to the concept of liberal state (an opinion Catharine MACKINNON has voiced).

Third-wave feminism, which emerges in the nineties of the last century, makes a very distinct reading of the role of sexuality and the inherent relations of power as a basis for defining the concept of patriarchy. Unlike the previous generation, it is thought that women do not need to be protected from the instruments of patriarchy (e.g. the objectification of women or pornography). The standing point of third-wave feminists appears to be established in permanent comparison with previous moments of feminism, in particular the ideas of the second wave, which they consider to be too defensive and doom women to give up enjoying the pleasure they also find in embracing social beauty standards, or the rules of relationship provided by the traditional patriarchal society ${ }^{10}$.

What is interesting to emphasise regarding these proposals is the fact it entails that women cease to be seen necessarily as victims of patriarchy to become perceived as participants in the game. It is acknowledged that women often draw advantages or pleasure from it. It is not a question of denying the existence of subordination relationships, but, rather, trying to express and understand the true feelings of real women in face of those relationships.

\section{MY BRILLIANT FRIEND AND FEMINISM}

${ }^{10}$ Janet HALLEY, a recognized voice in the context of the third wave, affirms its rejection of unique feminist thinking, which believes that the only way to be a feminist is to be anticapitalist, super-serious, and hostile to female hair removal and Madonna. Cfr. CRAWFORD 2010, 101. 
The novel we decided to analyse, and which paved the way for our reflection on the concept of patriarchy and its evolution in the context of feminist theories, is authored by Elena FERRANTE, pseudonym of an Italian writer. My Brilliant Friend (L'amica genial), throughout its 4 volumes, tells us the life story of Elena Grecco, as told in the first person.

Published on condition of anonymity, using that pseudonym, it seems relevant to clarify here that, even today, the identity of Elena FERRANTE, or even the person's gender, is not known for sure. There is much speculation, having circulated as more credible the thesis that it would be a woman, a professional translator.

As we said, the novel consists of the account of the protagonist's life, Elena Greco, but in fact it is her friendship (born in childhood and developing throughout life) with Lila that takes centre stage in the narrative. The plot is set in the city of Naples, in one of its poorest neighbourhoods, dominated by the camorra and the weight of secular traditions. In fact, the protagonist has the opportunity, throughout her life, to leave this neighbourhood and its native Naples, passing through several other Italian cities, such as Florence and Turin, but Naples will always be present on her journey and, subsequently, throughout the narrative. This happens not only because, unlike Elena, her friend Lila will not have the opportunity (or apparently the will) to leave Naples, but also because of the persisting friendship, as well as the family relationships, that helps to preserve the protagonist's bond with her roots. Moreover, the neighbourhood seems to gain existence and a life of its own and it is paramount in determining the protagonist's identity $^{11}$.

11 The protagonist herself is aware of this difficulty of freeing herself from the neighbourhood and the influence that it has, on a very profound level, on oneself. In an excerpt, Elena reflects on how the experience of women in the neighborhood seems to determine their physical degradation and loss of identity: "That day, instead, I saw clearly the mothers of the old neighbourhood. They were nervous, they were acquiescent. They 
Neapolitan society, which is described by Elena, does not cease to conjure images of Etore Scola's well-known 1970s satirical comedy, Brutti, sporchi e cattivi ${ }^{12}(1976)$. It is the epitome of patriarchal society, strongly dominated by gender roles, which the protagonist depicts ${ }^{13}$ as a particularly violent environment of people ostracised by society, living closed off in a world apart, in linguistic and cultural isolation propitiated by the use of dialect, with a clear social hierarchy, sedimented by that very violence.

In a way, throughout the narrative, we are always confronted with the protagonist's need to free herself from this petty, poor (in a multiple sense)

were silent, with tight lips and stooping shoulders, or they yelled terrible insults at the children who harassed them. Extremely thin, with hollow eyes and cheeks, or with broad behinds, swollen ankles, heavy chests, they lugged shopping bags and small children who clung to their skirts and wanted to be picked up. And, good God, they were ten, at most twenty years older than me. Yet they appeared to have lost those feminine qualities that were so important to us girls and that we accentuated with clothes, with makeup. They had been consumed by the bodies of the husbands, fathers, brothers, whom they ultimately came resemble, because of their labours or the arrival of old age, or illness. When did that transformation begin? With housework? With pregnancies? With beatings? [...] And would my body, too, one day be ruined by the emergence of not only my mother's body but my father's? And would all that I was learning at school dissolve, would the neighbourhood prevail again, the cadences, the manners, everything be confounded in a black mire, Anaximander and my father, Fólgore and Don Achille, valences and the ponds, aorists, Hesiod, and the insolent vulgar language of the Solaras, as, over the milleniums, had happened to the chaotic, debased city itself?" (chap. 22). FERRANTE 2013.

${ }^{12} \mathrm{Ugly}$, dirty and bad was the film title in English speaking countries.

${ }^{13}$ At the very beginning of her narrative, recalling her childhood in the neighbourhood, the protagonist states: "I feel no nostalgia for our childhood: it was full of violence. Every sort of thing happened, at home and outside, every day, but I don't recall having ever thought that the life we had there was particularly bad. Life was like that, that's all, we grew up with the duty to make it difficult for others before they made it difficult for us. Of course, I would have liked the nice manners that the teacher and the priest preached, but I felt That those ways were not suited to our neighbourhood, even if you were a girl. The women fought among themselves more than the men, they pulled each other's hair, they hurt each other. To cause pain was a disease". chap. 5 (childhood) FERRANTE 2012. 
and violent world she was born into. Elena Greco gains progressive awareness that, even going away, the neighbourhood will always be there with her: in her memory, through her friends and family that she leaves behind, in defining her own identity, in a complex love-hate relationship.

As we have already stated, the neighbourhood - the story's centre stage - is the epitome of patriarchal society, governed by constraining rules Elena and her friend Lila want to break free from. Despite sharing this common goal, the two friends will follow different paths. Elena will try to pursue emancipation through a successful educational journey, ensuring a rising social status and economic independence. This seems to offer her the way out from patriarchal society. Lila chooses a different way out of the neighbourhood. She seeks to elevate her social status by turning to marriage, a means of social climbing available to women in the patriarchal society. She accepts the marriage proposal from one of her neighbours, ${ }^{14}$ who seems to be able to grant her a better lifestyle than what is to be expected for women in her community.

In Lila's and Elena's paths towards emancipation, sexuality - and social standards constraining women's behaviour in this regard - is paramount to FERRANTE's novel, just like within feminist debate, as we have sought to demonstrate before. Indeed, Elena's and her friend Lila's willingness to affirm their sexuality will diversely confront those social standards. Once

${ }^{14}$ Lila's renewed social status is described by her friend Elena in a very striking way: "A few days had passed since the break with Gino when Lila confided that she had had two declarations almost at the same time, the first in her life. [...] The other declaration had come from Marcello Solara. In hearing that name I felt a pang. If Pasquale's love was a sign of how much someone could like Lila, the love of Marcello - a young man who was handsome and wealthy, with a car, who was harsh and violent, a Camorrist, used, that is, to taking the women he wanted - was, in my eyes, in the eyes of all my contemporaries, and in spite of his bad reputation, in fact perhaps even because of it, a promotion, the transition from skinny little girl to woman capable of making anyone bend to her will.". chap. 24 (adolescence). FERRANTE 2012. 
again, Lila is apparently more conformist and Elena is the one who seeks, and risks, a discovery of her body outside (or on the fringe) of the neighbourhood's traditional morality. ${ }^{15}$.

And yet, surprisingly, two episodes of the narrative, in which Lila takes centre stage, will show her resistance to traditional rules of sexual morality, which makes the body and image of women to be the property of men, be it their father, brothers or husband.

The first episode concerns the resistance Lila seeks against pregnancy as a newly married woman. This is an attitude that produces perplexity in Elena, convinced as she was of Lila's marital happiness and her apparent

15 The different way in which Elena and Lila address sexuality is something only the protagonist seems to be aware of and does take a long time to manifest. This is obvious to the reader in this dialogue between Lila and Elena, discussing their respective love affairs "«Do you and Stefano come here by yourselves? »

«Yes, sometimes. »

«And what happens?"

She looked at me as if she didn't understand.

«In what sense?»

I was embarrassed.

«Do you kiss?»

«Sometimes.»

«And then?»

«That's all, we're not married yet.»

I was confused. Was it possible? So much freedom and nothing? So much gossip in the neighbourhood, the Solaras' obscenities, and there had been only a few kisses?

«But he doesn't ask you? »

«Why, does Antonio ask you? »

«Yes.»

«No, he doesn't. He agrees that we should be married first. »

But she seemed struck by my questions, much as I was struck by her answers. So she yielded nothing to Stefano, even if they went out in the car by themselves, even if they were about to get married, even if they already had a furnished house, a bed with a mattress, still in his packing. And I, who certainly would not get married, had long ago gone beyond kissing.". chap. 51 (adolescence). FERRANTE 2012. 
acceptance of the neighbourhood's "rules of play." When pregnancy finally happens, it is lived and presented as a fatality that, once and for all, ends Lila's dream (cherished and enthusiastically supported by her friend Elena) of going back to school ${ }^{16}$. In fact, Lila's attitude, throughout pregnancy, is characterised by not only psychological but also physical rejection of something she is not able to fight: her body no longer belongs to her ${ }^{17}$.

The second episode, which seems interesting for us to mention, coincides with Lila's newly wedded experience and her resistance to pregnancy, and emphasises her attitude and criticism towards the rules enforced on her by patriarchal society.

16 The news came as a shock to Elena, who cherished the idea of her friend - who she admired so much - could once again be her school mate: "«Yes, but: you lost the bet and now you have to go back to books.»

«Stop it, Lenù. »

«Stefano won't let you?»

«There's the new grocery, I'm supposed to manage it. »

«You'll study in the grocery. »

«No.»

«You promised. You said we'd get our diploma together. »

«No.»

«Why?»

Lila ran her hand back and forth over the cover of the book, ironing it. «I'm pregnant », she said." Chap.23. FERRANTE 2013.

${ }^{17}$ Lila produces brutal statements in this regard, of great rawness, to reveal a model of relationship with motherhood far from the social paradigm that tends to idealize it: "[...] she had known for a long time that as far as that shit [her husband] was concerned she was merchandise to barter. She had come because of the pregnancy. [...] It has no meaning, she said, not concealing her anguish. Men insert their thingy in you, and you become of box of flesh with a living doll inside. I've got it, it's here, and it's repulsive to me. I throw up continuously, it's my very stomach that can't bear it. I know I'm supposed to think beautiful things, I know I have to resign myself, but I can't do it, I see no reason for resignation and no beauty. Besides the fact, she added, that I feel incapable of dealing with children".

Elena FERRANTE, The story of a new name, English trad., Europa Editions, 2013, chap.24. 
On Lila's wedding day, her beauty is captured by the photographer's lens. This photograph is shown, with Lila's consent, in the window-shop of the dressmaker responsible for her wedding gown. Everyone comments on Lila's beauty. The Solara brothers, members of the camorra, who own a shoe store that sells a shoe model designed by Lila herself (which was expropriated from her, with the consent of the men of her family, while ignoring her will), express their wish to expose the photograph there. They plan to exhibit Lila's picture in a large poster inside the store. Lila seems to want to test her husband and leaves the decision to authorise the use of her image up to him. After some initial resistance, Lila's husband ends up saying yes, giving in to the economic rise the Solara brothers possess over him and his family. For Lila, this is confirmation that, for her husband, she is a commodity, an asset owned by him ${ }^{18}$. What is at stake, deep down, is the awareness that women, their bodies, are ultimately objects. Cleverly, with Elena's help, Lila ends up convincing the Solaras to allow an artistic destruction/reconstruction of her image. This comes as a symbol of what will be her process of liberation from marriage and the neighbourhood's oppressive hierarchical relations ${ }^{19}$.

18 “"They placated Michele», she said, «just as they placated Marcello. They used me - to them I'm not a person but a thing. Let's give him Lila, let's stick her on a wall, since she's a zero, an absolute zero.» [...]

«Forget it, Lila. Ultimately, it's a nice thing, think about it: they only put actresses on billboards. »

«And am I an actress?»

«No.»

«So? If my husband has decided to sell himself to the Solaras, do you think he can sell me as well? » Chap. 25. FERRANTE 2013.

${ }^{19}$ It is Lila herself who will explain her sense of rejection of the social role imposed on her, and to what extent she perceives it as a true annulment of her personal identity: "Today, in the light of many subsequent events, I'm quite sure that that is really what happened. With the black paper, with the green and purple circles that Lila drew around certain parts of her body, with the blood red lines with which she sliced and said she was slicing it, she completed her own self-destruction in an image, presented to the eyes of all in the space 
FERRANTE's novel also gives us the possibility of staging, in the narrative of Elena Greco's life, the diverse reality of women's life experiences, of their different perspectives on issues such as sexuality and motherhood. Thus, Elena's character will eventually engage in an extramarital relationship, despite living a seemingly happy marriage with a devoted husband. The description of the impulsive (almost explosive) way the protagonist ends up living her love affair, not hesitating to abandon her daughters in the care of paternal grandparents to be with her lover, contrasts with the traditional image of women as victims of men, that certain strands of feminist scholarship have depicted.

What draws our attention is the way Elena's character, at this stage of the story, appears totally disconnected from the traditional, almost biological, characterisation of women. Moreover, this is in tune with some of the ideas expressed by current feminist theories. Elena puts herself as a priority, over her daughters, lets herself be dragged by her emotions and decides to experience them intensely at all costs. However, simultaneously, she feels the burden ${ }^{20}$ of violating the morality standards she was taught to live by.

bought by the Solaras to display and sell her shoes. [...] While we worked, she began to talk about when she had begun to realize that she was now Signora Carracci. At first, I didn't really understand what she was saying, her observations seemed to me banal. When, as girls, of course, we were in love, we would try out the sound of our name joined to the last name of the beloved[...]

Did it mean that if I were to write to her I would no longer address the letter to Raffaella Cerullo but to Raffaella Carracci? [...] Yes. A custom. Everything according to the rules, then. But Lila, as usual, hadn't stopped there, she had soon gone further. As we worked with brushes and paints, she told me that she had begun to see in that formula an indirect object of place to which, as if Cerullo Carracci somehow indicated that Cerullo goes toward Carracci, falls into it, is sucked up by it, is dissolved in it. [...] Raffaela Cerullo, overpowered, had lost her shape and had dissolved inside the outlines of Stefano, becoming a subsidiary emanation of him: Signora Carracci". Chap. 26. FERRANTE 2013.

${ }^{20}$ Elena lives the permanent tension of being, at the same time, happy and unhappy, torn between what she desires to experience as a woman and her love of her daughters: "That was the first clash with my in-laws. Others followed, though they never reached such 
Her mother and her mother-in-law, though coming from different social backgrounds, will both make bitter recriminations about her behaviour, censoring Elena for deciding to leave her loving husband.

This episode is particularly interesting in view of all the changes caused, in recent years, by a more egalitarian understanding of parental relationships, with relevant impacts on the understanding of motherhood and paternity. We witness the deconstruction of the paradigm of women umbilically attached to their children, as opposed to a more distant or "detached" father figure.

Elena Greco, in the confrontation with her mother-in-law - a privileged, educated woman, member of the Italian social elite -, fully assumes her choices and refuses to play by the traditional rules that, after all, her motherin-law accepted. At one point, she ends up denouncing the hypocrisy of her mother-in-law's position, as the latter had also maintained an extramarital relationship:

«Pietro told me you've had lovers.»

«I?»

explicit contempt. Later my in-laws confined themselves to demonstrating in every possible way that, if I insisted on being concerned with myself above all, I had to entrust Dede and Elsa to them.

I resisted, naturally: there was not a day that I didn't get angry and decide to take my children away with me immediately, to Florence, to Milan, to Naples - anywhere, just so as not to leave them in that house not let them stay in that house a moment longer. But soon I would give in, put off my departure; something always happened that bore witness against me. Nino, for example, telephoned and, unable to refuse, I rushed to meet him wherever he wanted. [...] I separated from them unwillingly. I felt their accusing gaze on me, and I suffered. And yet, already on the train, as I studied, as I prepared for some public discussion, as I imagined my meeting with Nino, an impudent joy began to bubble up inside me. I soon discovered that I was getting used to being happy and unhappy at the same time, as if that were the inevitable new law of my life." Chap. 17. FERRANTE 2015. 


\section{Clara Calheirosl ElenaFerrantiand Patriarchyl ISSN 2675-1038}

«You, yes, don't be so taken aback. I assumed my responsibilities in front of everyone, even Dede and Elsa, and I am paying for the consequences of my actions. You, who give yourself so many airs, you are just a hypocritical little bourgeois who hides her dirt under the carpet. $»^{21}$.

Elena's mother's reaction is more brutal, violent, in line with the environment in which she had always lived: the neighbourhood of her native Naples. Still, it is, in this regard, close to that of Elena's mother-inlaw, so far away from her in everything else, but not apparently when it comes to certain patterns of morality that women should not condone.

\section{ELENA AND LILA. FINAL REMARKS}

Elena and Lila are, therefore, two women who challenge the archetypes of patriarchal society, but without turning into heroines, avengers of the genre, heralds of morality. The two friends are, in FERRANTE's novel, people who embody the difficulties emerging from living their condition as poor women, born in a ostracised community, in the context of a strongly hierarchical patriarchal society.

Therefore, in the description of the characters, in their characterisation through the stories they experience, we do not find an attempt, through them, to present an ideal of womanhood, being endowed with special virtues, and holders of moral superiority vis-a-vis man.

${ }^{21}$ Chap. 24. FERRANTE 2015. 
The image of these two friends, whose adventures and misadventures go through the four volumes of FERRANTE's novel, is, therefore, more evocative, in my opinion, of the vision of women provided to us by thirdwave feminism. As the story unfolds, there are multiple examples of Lila's and Elena's capacity to identify themselves as women, in a hostile and violent world, in constant tension against the dominating yoke of patriarchal society. However, Elena's and Lila's reaction is, frequently and surprisingly, to enjoy themselves accepting to play by the rules of the traditional typical subordination in man-woman relationships.

The two characters appear, in the eyes of readers, with the richness of the complexity of women's real lives, allowing the understanding of their circumstance and condition, of how they suffer the inherent adversities first-hand. At the same time, we realize, in their desires and impulses, the ability to make very questionable choices, the temptation to make use of their sex characteristics in order to manipulate man and gain control over them in interpersonal relationships.

The relationship of both characters with motherhood is an eloquent example of the deconstruction of the "natural" female image. Neither of the two friends clearly corresponds to the ideal of the selfless mother, dominated by the protective instinct of the children, ready to sacrifice themselves, in every aspect of life, for their children's sake. Both can give priority to their dreams and ambitions; they are women before they are mothers.

Elena FERRANTE seems to have been able to draw two female characters who, rather than embodying the most radical feminist ideas, are in great harmony with the experience and life projects of real women. After all, real women are so different from each other, even if we consider them equal.

And so that's why this novel is so eloquent in the portrait presented complex, multifaceted, ambiguous even - of what it ultimately means to be a woman living in a patriarchal society. 


\section{REFERENCES}

CAINE, Patricia, "Feminist Legal Scholarship”, Iowa Law Review, 19, 1992.

CRAWFORD, Bridget J., "The third wave's break from feminism", International Journal of Law in Context, 6, Cambridge University Press, 2010, 100-102.

EISENSTEIN, Zillah R., The Female Body and the Law, Berkeley, University of California Press, 1988

FERRANTE, Elena, My brilliant friend, Europa Editions, 2012

FERRANTE, Elena, Story of the lost girl. Europa Editions: 2015

FERRANTE, Elena, The story of a new name, Europa Editions, 2013

HIGGINS, Charlotte, "The age of patriarchy: how an unfashionable idea became a rallying cry for feminism today", The Guardian, https://www.theguardian.com/news/2018/jun/22/the-age-of-patriarchyhow-an-unfashionable-idea-became-a-rallying-cry-for-feminism-today [last access 14.01.2020]

IRONS, Courtney, "The Patriarch and the Sovereign: The Malheur Occupations and the Hyper-Masculine Drive for Control" Columbia Journal of Law and Social Problems, 2018, 479-522

KALSEM, Kristin \& WILLIAM, Verna, "Social Justice Feminism", UCLA Womens' Law Journal, 2012.

MACKINNON, Catharine A., Toward a Feminist Theory of the State. Cambridge, Harvard University Press, 1989 
MILLET, Kate, "What is to be done", Chicago-Kent Law Review, 2000, 659668.

SMART, Carol, Feminism and the Power of Law, London, Routledge, 1989.

WILLIAMS, Verna, "The Patriarchy Prescription: Cure Or Containment Strategy", Georgetown Journal of Law \& Modern Critical Race Perspectives, 2016, 61-84;

WOOLF, Virginia, Three Guineas. http://gutenberg.net.au/ebooks02/0200931h.html [last access 14.01.2020] 